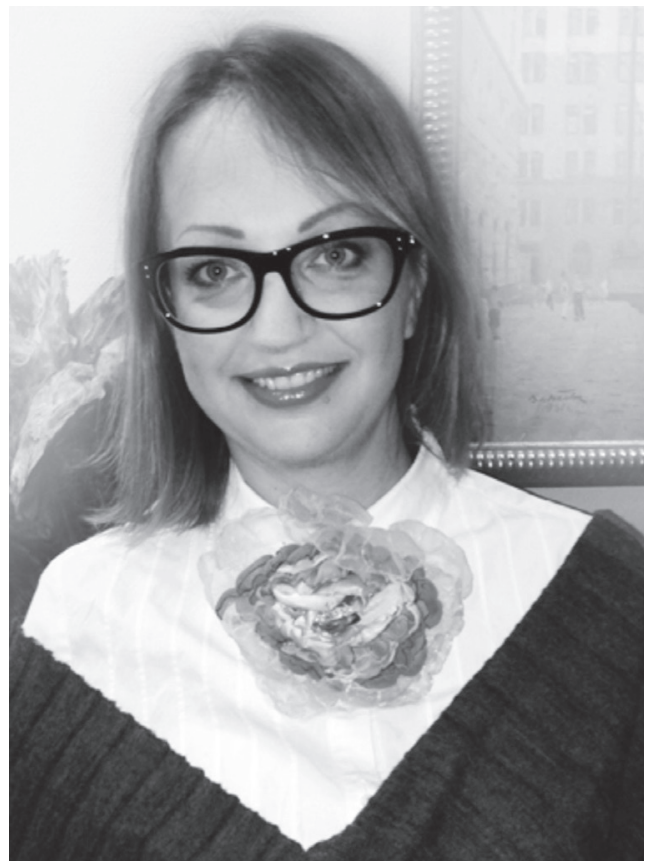

УДК : 351.329:336.58

DOI: https://doi.org/10.32689/2617-

2224-2019-17-2-110-123

\section{Кустова Світлана Миколаївна,}

аспірант кафедри парламентаризму та політичного менеджменту, Національна академія державного управління при Президентові України, заслужений юрист України. 02000, Україна, Київ, вул. Ежена Потьє, 20, тел.:+38 (066) 03071 58, e-mail: pravoved1996@ukr.net

ORCID: 0000-0002-5387-222X

Кустова Светлана Николаевна, аспирант кафедры парламентаризма и политического менеджмента, Начиональная академия государственного управления при Президенте Украины, заслуженный юрист Украины. 02000, Украина, Киев, ул. Эжена Потье, 20, тел.:+38 (066) 03071 58,e-mail: pravoved1996@ukr.net

ORCID: 0000-0002-5387-222X

Kustova Svitlana Mykolayivna,

PhD student of the Department of Parliamentarism and Political Management of the National Academy of Public Administration under the President of Ukraine, Honored Lazyer of Ukraine, 02000, Ukraine, Kyiz, Str. Ezhena Potier, 20, tel.: +38 (066) 03071 58, e-mail: pravoved1996@ukr.net

ORCID: 0000-0002-5387-222X

\title{
ОСНОВНІ ПРИНЦИПИ РЕГУЛЮВАННЯ ДЕРЖАВНОГО ФІНАНСУВАННЯ ПОЛІТИЧНИХ ПАРТІЙ: ДОСВІД КРАЇН РОЗВИНЕНОÏ ДЕМОКРАТІЇ ТА УКРАÏНА
}

Анотація. Розглянуто узагальнений досвід країн розвиненої демократії щодо правових засад державного регулювання фінансування політичних партій та практичні можливості використання його в Україні. Проаналізовано положення законопроектів щодо змін у системі державного регулювання фінансування політичних партій в Україні та запропоновано шляхи її вдосконалення.

Показано, що досвід державного фінансування політичних партій в країнах розвиненої демократії, зокрема в країнах Європи, є успішним. Зазначено, що ефективність та дієвість системи фінансування політичних партій не залежить від наявності в ній спеціального закону щодо фінансування. 
Наголошується, що такі суспільні відносини можуть бути врегульовані як окремими законодавчими актами, так і у вигляді системи положень в різних законах - конституціях, законах про партії, виборчому законодавстві, законах про боротьбу з корупцією.

Аргументується, що державне фінансування політичних партій є одним із дієвих інструментів у боротьбі з політичною корупцією та забезпеченні партій необхідними ресурсами для статутної діяльності та розвитку.

Наведено приклади європейського досвіду державного фінансування діяльності політичних партій, які мають великий рейтинг, і тих, що тільки висувають кандидатів на виборах. Це може гарантувати рівність можливостей для різних політичних сил. Отже, державне фінансування має визначатися пропорційно до політичної підтримки, яку партія отримала. Водночас надмірна залежність від державного фінансування може призвести до послаблення зв'язків між партіями та їхнім електоратом.

У європейському досвіді виокремлюють державне та приватне фінансування політичних партій. Державне відбувається як фінансування статутної діяльності та як фінансування витрат на виборчі кампаніі. Воно буває пряме (субсидіювання) та непряме (вигоди на законодавчій підставі). Встановлено, що державна підтримка політичних партій у країнах Європи коливається в межах від 20 до 85 \% від загального бюджету партій.

Досвід країн розвиненої демократії має бути врахований в Україні з метою вирішення вже існуючих проблем та уникнення їх у майбутньому, що посилить партійну конкуренцію, внутрішньопартійну демократію, забезпечить належну реалізацію функції політичних партій як сполучної ланки між громадянським суспільством та державою.

Ключові слова: фінансування політичних партій, державне регулювання, державне управління, фінансова звітність, поняття державного фінансування партій.

\section{ОСНОВНЫЕ ПРИНЦИПЫ РЕГУЛИРОВАНИЯ ГОСУДАРСТВЕННОГО ФИНАНСИРОВАНИЯ ПОЛИТИЧЕСКИХ ПАРТИЙ: ОПЫТ СТРАН РАЗВИТОЙ ДЕМОКРАТИИ И УКРАИНА}

Аннотация. Рассмотрен обобщенный опыт стран развитой демократии относительно правовых основ государственного регулирования финансирования политических партий и практические возможности использования его в Украине. Проанализированы положения законопроектов об изменениях в системе государственного регулирования финансирования политических партий в Украине и предложены пути ее совершенствования.

Показано, что опыт государственного финансирования политических партий в странах развитой демократии, в частности в странах Европы, является успешным. Отмечено, что эффективность и действенность системы финансирования политических партий не зависит от наличия в ней специального закона о финансировании. Отмечается, что такие общественные отношения могут быть урегулированы как отдельными законодательными актами, так и 
в виде системы положений в различных законах - конституциях, законах о партиях, избирательном законодательстве, законах о борьбе с коррупцией.

Аргументируется, что государственное финансирование политических партий является одним из действенных инструментов в борьбе с политической коррупцией и обеспечении партий необходимыми ресурсами для уставной деятельности, их развития.

Приводится пример европейской практики государственного финансирования деятельности политических партий, которые имеют большой рейтинг, и тех, кто только выдвигают кандидатов на выборах. Это может гарантировать равенство возможностей для различных политических сил. Итак, государственное финансирование должно определяться пропорционально политической поддержкой, которую партия получила. Вместе с тем, чрезмерная зависимость от государственного финансирования может привести к ослаблению связей между партиями и их электоратом.

В европейском опыте выделяют государственное и частное финансирование политических партий. Государственное финансирование происходит как финансирование уставной деятельности и как расходов на избирательные кампании. Оно бывает прямое (субсидирование) и косвенное (льготы на законодательной основе). Установлено, что государственная поддержка политических партий в странах Европы колеблется в пределах от 20 до 85 \% от общего бюджета партий.

Опыт стран развитой демократии должен быть учтен в Украине с целью решения существующих проблем и предотвращения их в будущем, что усилит партийную конкуренцию, внутрипартийную демократию, обеспечит надлежащую реализацию функции политических партий в качестве связующего звена между гражданским обществом и государстBOM.

Ключевые слова: финансирование политических партий, государственное регулирование, государственное управление, финансовая отчетность, понятие государственного финансирования партий.

\section{MAIN PRINCIPLES FOR REGULATION OF PUBLIC FINANCING OF POLITICAL PARTIES: EXPERIENCE OF DEVELOPED DEMOCRACY COUNTRIES AND UKRAINE}

Abstract. The article considers the generalized experience of developed democracies in relation to the legal foundations of state regulation of financing of political parties and the practical possibilities of using it in Ukraine. The article analyzes the provisions of the draft laws on changes in the system of state regulation of financing of political parties in Ukraine and suggests ways to improve it.

It has been shown that the experience of state funding of political parties in developed democracies, in particular, in European countries, is successful. It is noted that the efficiency and effectiveness of the system of financing political parties does not depend on the existence of a special law on financing. It is noted that 
such social relations can be regulated as separate legislative acts, as well as in the form of a system of provisions in various laws - constitutions, party laws, electoral legislation, anti-corruption laws.

It is argued that state financing of political parties is one of the effective tools in the fight against political corruption and provision of parties with the necessary resources for statutory activities and their development.

The author draws attention to the European practice of state financing of the activities of political parties, which have a high rating, and those that only nominate candidates for elections. This can guarantee equality of opportunity for various political forces. So, public funding must be determined in proportion to the political support that the party has received. At the same time, the author is convinced that excessive dependence on state financing may lead to a weakening of ties between parties and their electorate.

The article also states that in the European experience state and private funding of political parties is allocated. Public financing takes place both by statutory activities and by campaign expenditures. It is direct (subsidizing) and indirect (benefits on a legislative basis). It is established that the state support of political parties in European countries ranges from more than $20 \%$ to $85 \%$ of the total budget of parties.

The author is convinced that the experience of developed democracies should be taken into account in Ukraine with the aim of solving existing problems and preventing them in the future, which will strengthen party competition, internal party democracy, and ensure the proper realization of the function of political parties as a connecting link between civil society and the state.

Keywords: financing of political parties, state regulation, state administration, financial reporting, concept of state financing of parties.

Постановка проблеми. Для України дослідження правового регулювання фінансування політичних партій має особливу актуальність у контексті ще досить малого досвіду функціонування норми у Законі України "Про політичні партії в Україні” [1], яка набула чинності 1 липня 2016 р. [2], що запровадила державне фінансування політичних партій. Адаптація зарубіжного досвіду державного регулювання фінансування діяльності політичних партій в Україні має особливе значення для розвитку демократії та підви- щення ефективності функціонування влади.

Аналіз останніх публікацій за проблематикою та визначення невирішених раніше частин загальної проблеми. У другій половині ХХ ст. питання державного фінансування статутної діяльності політичних партій розглядалося науковцями переважно у контексті проблем соціально-політичного розмежування, структурування суспільства та його демократизації (праці С. Бартоліні [3], П. Мейра [4], І. Баджа [5], Х. Кемана [6], М. Левера [7], Н. Шо- 
філда [8], В. Ханта [9], О. Нідермайеpa [10], К. Джанди [9], Р. Хермела [9], К. Еденса [9], П. Гоффа [10], Р. Делтона [11-13], С. Фленегена [15], А. Вера [16], Л. Хелмса [17]). В Україні останнім часом тема фінансування політичних партій стала об’єктом досліджень науковців - Л. Гонюкової [18], О. Коцюруби [19], С. Обушного [20], М. Примуша [21], Р. Мартинюка [22], А. Романюка [23], Ю. Шведи [23] та О. Шумельда [23] як у контексті більш загальних питань та проблем структурування суспільств, так і в зв'язку з питаннями підзвітності влади, ефективності функціонування та справедливого механізму державного регулювання.

Формулювання цілей статті (постановка завдання). Метою статті $€$ дослідження та висвітлення окремих особливостей зарубіжного досвіду державного регулювання фінансування діяльності політичних партій в історичному контексті та можливостей його адаптації в Україні. Виходячи з поставленої мети, основними завданнями у статті вбачаємо завдання проаналізувати принципи та форми державного фінансування політичних партій в країнах розвиненої демократії в історичному контексті та запропонувати шляхи вдосконалення механізмів державного регулювання щодо фінансування політичних партій в Україні.

Виклад основних результатів. Державне фінансування сприяе ідеологізації новостворених партій, крім того партії легко до нього звикають і вже не можуть без нього обходитися. Але, на нашу думку, основні переваги бюджетної підтримки політичних партій - це стимулювання розвитку політичної конкуренції, підвищення інтенсивності та якості політичної боротьби (за рахунок взяття участі у ній менш заможних, але більш ідейних партій), робить фінансово незалежними ті партії, які вже сьогодні мають високий рівень підтримки 3 боку громадян.

Згідно із застосованим В. В. Джуган визначенням, “фінансування політичних парій - це здійснювана в порядку та в межах, встановлених чинним законодавством, діяльність політичних партій, органів державної влади, фізичних та юридичних осіб, яка спрямована на забезпечення політичних партій фінансовими та іншими ресурсами, які піддаються фінансовій оцінці і які необхідні політичним партіям для реалізації своїх цілей та завдань” [24].

Принципи, на яких має грунтуватися фінансування, стали об'єктом наукового дослідження 3 початку цього століття. Так, основні принципи здійснення регулювання державного фінансування політичних партій представлено у монографії Л. Янга "Регуляція політичного фінансування у ліберально-демократичних суспільствах" [25]. Автором досліджено сильні та слабкі сторони різних підходів до регламентування фінансового забезпечення виборчих кампаній та розглянуто теоретичні питання, які є основами такого фінансування. У науковій праці за редакцією Р. Вільямса "Партійне фінансування та політична корупція" [26] здійснюється поглиблене дослідження партійного фінансування та проблем політичної корупції. Автор зауважує, що “джерела, масштаби, форми, розподіл партійного фінан- 
сування мають глибокі політичні наслідки" [26, с. 5]. Отже, цей процес має бути регламентованим, базуватися на чітких принципах.

Основні принципи державного фінансування політичних партій в країнах розвиненої демократії, зокрема в країнах Свропи, сьогодні є об'єктом дослідження й вітчизняних експертів. Експертом Національного інституту стратегічних досліджень при Президентові України С. Янішевським [27] з цією метою проаналізовано документи Венеціанської комісіі, ПАРЕ, Комітету міністрів Ради Європи [28-31]. В. Джуган здійснено порівняльний аналіз конституційно-правових засад фінансування політичних партій в Україні та країнах ЄC [32]. Загалом, наслідки державного фінансування політичних партій досліджуються 3 середини минулого століття. Висновки дослідників з цього приводу неоднозначні. Наприклад, К. Стром [33] висунув теорію, згідно з якою державне фінансування збільшує незалежність партійних лідерів від активістів, у той час як Дж. Шлезінджер [34] вважає, що воно сприяє бюрократизації партій. Натомість проведене К.-Х. Нассмахером [35] дослідження механізму державних субсидій партіям в Австрії, Італії, Швеції та Нiмеччині свідчить про те, що обидва висновки мають право на існування.

Аналіз вказаних джерел дає можливість встановити, що державне регулювання фінансування політичних партій базується на таких принципах, як рівноправність, багатоманітність джерел фінансування, пропорційність, розумність та обгрунтованість балансу між державним i приват- ним фінансуванням, справедливість розподілу державного фіксування між партіями, обмеження приватного фінансування за характером i розміром, прозорість фінансування, та підзвітність. Вони означають те, що публічне фінансування має бути призначене для кожної партії, представленої в парламенті.

Публічне фінансування може бути поширене як на політичні органи, які представляють важливу частину електорату, так і на ті, що висувають кандидатів на виборах, що гарантує рівність можливостей для різних політичних сил. Державне фінансування має визначатися пропорційно до політичної підтримки, яку партія отримала. В основі має бути також об'єктивність, а саме, фінансування базується на розрахунках з урахуванням таких об'єктивних критеріїв, як кількість поданих голосів або здобутих місць у парламенті та надавати новим партіям можливість з'являтися на політичній арені, конкуруючи на чесних умовах з партіями, які мають давні міцні позиції. Надмірна залежність від державного фінансування може призвести до послаблення зв’язків між партіями та їнім електоратом. Політична партія на європейському рівні має публікувати щороку доходи, витрати і декларацію щодо своїх активів і пасивів, декларувати джерела фінансування шляхом надання списку, що вказує дарувальників, і отримані від кожного дарувальника презенти, що перевищують 500 євро.

Щодо форм фінансування, то виокремлюють державне та приватне фінансування. Державне відбувається як фінансування статутної ді- 
яльності, як фінансування витрат на виборчі кампанії політичних партій. Бюджетне фінансування поділяють на пряме фінансування (субсидіювання) та непряме (вигоди на законодавчій підставі), зокрема шляхом покриття поштових витрат та оренди приміщень для зустрічей, підтримки партійних засобів масової інформації, молодіжних організацій та дослідницьких інститутів, а також, надаючи податкові пільги, тощо [36]. Державне фінансування отримують як парламентські партії, так і партіï, які не потрапили до парламенту. Загалом державна підтримка політичних партій у країнах Європи коливається у межах від 20 до 85 \% від загального бюджету партій [37].

В українському суспільстві дискуciï з приводу фінансування політичних партій з державного бюджету та напрями витрат цих коштів політичними партіями часто мають негативний зміст та незначну підтримку. У 2015 р. лише 15 \% громадян підтримували фінансування партій з бюджету, у 2016 р. - 15,7 \%, у 2017 р. - 9,9\% вважали фінансування 3 бюджету держави прийнятним. Невелика чисельність громадян підтримують фінансування державою політичних партій, оскільки мало громадян їм довіряють - до і після 2013 р. цим інституціям довіряли не більше п'ятої частини опитуваних [38].

Щодо основних недоліків, то, на нашу думку, на це звернули увагу ще у другій половині минулого століття - є певні проблеми щодо джерел фінансування партій, особливо щодо державного фінансування, 3 якими пов'язані політична конкуренція, прозорість діяльності та підзвітність партій, залежність політичної та державної влади, корупція. Д. Цацос, М. Боте, А. Блекман у праці “Фінансування політичних партій: порівняльно-правове дослідження" [39], проаналізувавши законодавство ФРН, Швеції, Франції, Великобританії, Італії та інших країн, виявили потребу розвитку державних інструментів регулювання фінансування політичних партій та показали необхідність вдосконалення законодавства, зауваживши, що недосконалий механізм контролю за фінансуванням політичних партій, у тому числі і за державним фінансуванням, є причиною проблем державного управління. Крім того, П. Копецкі встановив, що серед недоліків бюджетного фінансування є те, що багато партій у країнах південної Свропи практично повністю залежать від держави, а в інших країнах - державне фінансування є “символічним” порівняно 3 приватними та корпоративними пожертвуваннями [40, с. 262].

В Україні суспільні відносини у сфері публічного управління та адміністрування щодо державного фінансування політичних партій регулюються Конституцією України [41], законами України "Про політичні партії в Україні” [42], “Про вибори народних депутатів України” [43]. Визначено форми та обсяг державного фінансування політичних партій, порядок виділення та розподілу між політичними партіями коштів на фінансування їхньої статутної діяльності, підстави припинення державного фінансування, тощо. Але з того часу є низка окремих питань щодо практичної реалізації положень Закону України “Про політичні партії в 
Україні” в частині порядку розподілу між політичними партіями коштів на фінансування їхньої статутної діяльності, обсягів фінансування політичних партій, строку використання політичними партіями коштів на фінансування їхньої статутної діяльності. У цьому зв'язку з 2016 р. (часу запровадження норми про фінансування) у законодавчому органі час від часу законотворці реєструють проекти законів щодо удосконалення державного регулювання фінансування політичних партій та навіть скасування такого.

Зауважимо, що узагальнений досвід державного фінансування політичних партій в країнах Свропейського Союзу свідчить про необхідність чіткої регламентації на законодавчому рівні порядку здійснення державної фінансової підтримки партій. Урахування досвіду фінансування політичних партій в країнах Європейського Союзу дасть можливість в Україні вдосконалити порядок державного фінансування політичних партій, запровадити чіткий механізм розподілу між політичними партіями коштів на фінансування їхньої статутної діяльності, прозорість такого фінансування та належний фінансовий контроль. Вирішувати ці проблеми покликані зареєстровані у Верховній Раді України законопроекти від 24.11.2016 р. № 5446 та від 03.02.2017 р. № 6026 про внесення змін до законів України щодо цільового використання державного фінансування статутної діяльності політичних партій.

Висновки. Питання доцільності та необхідності фінансування політичних партій за рахунок коштів державного бюджету гостро дискутується не лише в Україні, а й в багатьох країнах Європейського Союзу, де воно успішно діє впродовж досить тривалого періоду. Узагальнення досвіду державного фінансування політичних партій в країнах розвиненої демократії, зокрема в окремих країнах Європи, на найвищому рівні європейських офіційних інституцій свідчить про те, що загалом, за виключенням Італії, цей досвід є успішним. Ефективність та дієвість системи фінансування політичних партій не залежить від наявності в ній спеціального закону щодо фінансування, оскільки, як свідчить досвід країн Європи, ці суспільні відносини можуть бути врегульовані як окремими законодавчими актами, так і у вигляді системи положень в різних законах - конституціях, законах про партії, виборчому законодавстві, законах про боротьбу з корупцією тощо. Державне фінансування політичних партій є одним із дієвих інструментів у боротьбі 3 політичною корупцією та забезпеченні партій необхідними ресурсами для статутної діяльності та розвитку. Досвід країн розвиненої демократії має бути врахований в Україні з метою вирішення вже існуючих проблем та уникнення ї у майбутньому, що посилить партійну конкуренцію, внутрішньопартійну демократію, забезпечить належну реалізацію функції політичних партій як сполучної ланки між громадянським суспільством та державою.

\section{СПИСОК ВИКОРИСТАНИХ ДЖЕРЕЛ}

1. Про політичні партії в Україні: Закон України від 2001 р. № 2365-III // 
Відомості Верховної Ради України. -2001 . - № 23. - Ст. 118. URL: https://zakon.rada.gov.ua/laws/ show/2365-14 (Дата звернення: 05.01.2019).

2. Про внесення змін до деяких законодавчих актів України щодо запобігання і протидії політичній корупції: Закон України від 2015 р. № 731-VIII // Відомості Верховної Ради України. - 2015. - № 49-50. Ст. 449. URL: https://zakon.rada. gov.ua/laws/show/731-19\#n60 (дата звернення: 05.01.2019).

3. Bartolini St. Identity, competition, and electoral availability. The stabilization of European electorates 1885-1985. Cambridge: Cambridge University Press, 1990. -383 p.

4. Dalton R. J. Political parties and political representation. Party supporters and party elites in nine nations. Comparative political studies. London, Thousand Oaks, New Dehli, 1985. Vol. 18. N. 3.

5. Budge I., Keman H. Parties and democracy. Coalition formation and government functioning in twenty states. $\mathrm{Ox}$ ford, 1990.

6. Budge I., Keman H. Parties and democracy. Coalition formation and government functioning in twenty states. $\mathrm{Ox}$ ford, 1990.

7. Laver M., Hunt W. B. Policy and party competition. New York, 1992.

8. Laver M., Schofield N. Multiparty government. The politics of coalition in Europe. Oxford, New York, 1990.

9. Laver M., Hunt W. B. Policy and party competition. New York, 1992.

10. Janda K., Harmel R, Edens C., Goff P. Changes in party identity: evidence from party manifestos // Party politics. London, Thousand Oaks, New Dehli, 1995. Vol. 1. № 2.

11. Dalton R.J. Political parties and political representation. Party support- ers and party elites in nine nations. Comparative political studies. London, Thousand Oaks, New Dehli, 1985. Vol. 18. № 3.

12. Dalton R. J. Citizen politics: public opinion and political parties in advanced western democracies. Chatham, 1996.

13. Dalton R.J., Flanagan S. C, Beck P. A. (eds.). Electoral change in advanced industrial democracies: realignment or dealignment? Princeton, 1984.

14. Dalton R. J., Flanagan S. C, Beck P. A. (eds.). Electoral change in advanced industrial democracies: realignment or dealignment? Princeton, 1984.

15. Niedermayer $O$. Zur systematischen analyse der entwicklung von parteiensystemen // wahlen und politische einstellungen in westlichen demokratien / O. W. Gabriel, J. W. Falter, (hrsg.). Frankfurt am Main U. A., 1996.

16. Ware A. Political parties and party systems. Oxford, New York, 1996.

17. Helms $l$. Parteien und fraktionen. Ein internationaler vergleich. Opladen, 1999.

18. Гонюкова Л. Політичні партії як інститут державної політики та управління: теоретико-методологічний аналіз: монографія. - К., 2009. $392 \mathrm{c}$.

19. Коцюруба О. Публічне фінансування політичних партій: перспектива для України на досвіді Польщі // Вісн. Львівського ун-ту. Серія юридична. - 2013. - № 57. - С. 179-188.

20. Обушний C. М. Фінансове забезпечення діяльності політичних партій в Україні: дис. ... канд. екон. наук : 08.00.08. - K., 2007. - 186 c.

21. Примуш М. В. Політико-правове регулювання діяльності політичних партій: монографія. - Донецьк, 2001. $-338 \mathrm{c}$.

22. Мартинюк $P$. Партійна система України та регіональні чинники в iï розвитку. Політологічні та соціо- 
логічні студії // Зб. наук. пр. П50 T.IX. - Чернівці, 2010. - С. 180-192.

23. Романюк А. С., Шведа Ю. Р., Шумельда О. В. Політико-правові аспекти фінансування політичних партій: світовий досвід та Україна. - Л., 2003. - 132 c.

24. Джуган B. В. Конституційно-правові засади фінансування політичних партій в Україні та країнах СС: порівняльний аналіз: дис. ... канд. юрид. наук (доктора філософії) за спец. 12.00.06 "Конституційне право; муніципальне право”. Ужгород. нац. ун-т. - Ужгород, 2017. - С. 82.

25. Янг Л. Регуляція політичного фінансування у ліберально-демократичних суспільствах: монографія. Київ, 2002. - 96 с.

26. Williams R. Aspects of Party Finance and Political Corruption. In Party Finance and Political Corruption. 2000. - London: Macmillan. - 214 p.

27. Янішевський C. О. Державне фінансування статутної діяльності політичних партій: досвід $\mathrm{CC}$ і напрями удосконалення вітчизняного законодавства. Аналітична записка. Нац. ін-т стратегічних досліджень. URL: http://www.niss.gov. ua/articles/2900/ (Дата звернення: 05.01.2019).

28. Керівні принципи та доповідь щодо фінансування політичних партій (Венеціанська Комісія (0910).03.2001 (CDL-INF(2001)008)).

29.Рекомендації Парламентської Асамблеї Ради Свропи від 22 травня 2001 р., № 1516. Фінансування політичних партій. URL: http://crimecor. rada.gov.ua/komzloch/control/uk/ publish/article;jsessionid $=$ DCB18A (дата звернення: 05.01.2019).

30. Рекомендація ПАРЕ “Фінансування політичних партій” від 22.05.2001 р. № 1516(2001).

31. Рекомендація Комітету Міністрів Ради Свропи “Про загальні правила боротьби з корупцією при фінансуванні політичних партій та виборчих кампаній” від 08.04.2003 p. Rec 2003 (4).

32. Джуган B. В. Конституційно-правові засади фінансування політичних партій в Україні та країнах СС: порівняльний аналіз: дис. ... канд. юрид. наук (доктора філософії) за спец. 12.00.06 “Конституційне право; муніципальне право”. Ужгород. нац. ун-т. - Ужгород, 2017. C. 82.

33. Strom K. A. Behavioral theory of competitive political parties // American journal of political science. Oxford, 1990. Vol. 34. - № 2.

34. Schlesinger Joseph A. On the Theory of Party Organization // The Journal of Politics 1984 46:2, 369-400 p.

35. Naßmacher Karl-Heinz. The Funding of Party Competition Baden-Baden (Nomos Verlag), 2009.

36. Financing of political parties : Recommendation 1516 (2001) : [adopted by Parliamentary Assembly of the Council of Europe on 22 May 2001]. URL: http://www.assembly.coe.int/ nw/xml/XRef/Xref-XML2HTMLen.asp?fileid=16907\&lang=en （дата звернення: 06.01.2019).

37. Biezen I. van. Campaign and party finance. URL:https://www.hks.harvard.edu/fs/pnorris/Acrobat/Chapter\%205\%20Van\%20Biezen\%20Campaign $\% 20$ and $\% 20$ party\%20finance. pdf (дата звернення: 05.01.2019).

38. "Моніторинг-2018: основні тенденції змін громадської думки”. Соціологічне опитування Інституту соціології НАН України та Фонду “Демократичні ініціативи" імені Ілька Кучеріва в рамках Програми сприяння громадській активності “Долучайся!”. URL: https://dif.org. ua/article/monitoring2018-osnovnitendentsii-zmin-gromadskoi-dumki (дата звернення: 06.01.2018). 
39. Tsatsos D., Bleckmann A., Bothe M. Die Finanzierung politischer Parteien: ein rechtsvergleichender Uberblick. Zeitschrift für ausländisches öffentliches Recht und Völkerrecht. - 1965. № 25. - P. 524-550.

40. Kopecký P. Political parties and the state in post-communist Europe: The nature of symbiosis // Journal of Communist Studies and Transition Politics. - 2006. - № 22. - P. 251273, 262.

41. Конституція України: Закон України від 28 червня 1996 р. URL: http:// zakon2.rada.gov.ua/laws/show/254\% D0\%BA/96-\%D0\%B2\%D1\%80 (дата звернення: 05.01.2019).

42. Про політичні партії в Україні: Закон України від 2001 р. № 2365-III // Відомості Верховної Ради України. - 2001. - № 23. Ст. 118. URL: https://zakon.rada.gov. ua/laws/show/2365-14 (Дата звернення: 05.01.2019).

43. Про вибори народних депутатів України : Закон України від 25 березня 2004 p. URL: http://zakon5. rada.gov.ua/laws/show/1665-15/ ed20060318/page (дата звернення: 05.01.2019)

\section{REFERENCES}

1. Zakon Ukrainy "Pro politychni partii v Ukraini” : vid 01.10.2018, № 2365III [Law of Ukraine "On Political Parties in Ukraine” from 01.10.2018, № 2365-III]. (n.d.). zakon.rada.gov. ua. Retrieved from https://zakon. rada.gov.ua/laws/show/2365-14 [in Ukrainian].

2. Zakon Ukrainy "Pro vnesennia zmin do deiakykh zakonodavchykh aktiv Ukrainy shchodo zapobihannia i protydii politychnii koruptsii" : vid 08.10.2015, № 731-VIII [Law of Ukraine "On amendments to certain legislative acts of Ukraine on prevention and counteraction to po- litical corruption” from 01.10.2018, № 2365-III]. (n.d.). zakon.rada.gov. ua. Retrieved from https://zakon.rada. gov.ua/laws/show/731-19\#n60 [in Ukrainian].

3. Bartolini St. (1990). Identity, competition, and electoral availability. The stabilization of European electorates 1885-1985. Cambridge: Cambridge University Press [in English].

4. Dalton R. J. (1985). Political parties and political representation. Party supporters and party elites in nine nations. Comparative political studies, 8(3), 267-299 [in English].

5. Budge I., Keman H. (1990). Parties and democracy. Coalition formation and government functioning in twenty states. Oxford [in English].

6. Budge I., Keman H. (1990). Parties and democracy. Coalition formation and government functioning in twenty states. Oxford [in English].

7. Laver M., Hunt W. B. (1992). Policy and party competition. New York [in English].

8. Laver M., Schofield N. (1990). Multiparty government. The politics of coalition in Europe. Oxford, New York [in English].

9. Laver M., Hunt W. B. (1992). Policy and party competition. New York [in English].

10. Janda K., Harmel R., Edens C., Goff P. (1995). Changes in party identity: evidence from party manifestos. Party politics, 1(2), 171-196 [in English].

11. Dalton R. J. (1985). Political parties and political representation. Party supporters and party elites in nine nations. Comparative political studies, 8(3), 267-299 [in English].

12. Dalton R. J. (1996). Citizen politics: public opinion and political parties in advanced western democracies. Chatham [in English].

13. Dalton R.J., Flanagan S. C., Beck P. A. (Eds.). (1984). Electoral change in 
advanced industrial democracies: realignment or dealignment? Princeton [in English].

14. Dalton R. J., Flanagan S. C., Beck P. A. (Eds.). (1984). Electoral change in advanced industrial democracies: realignment or dealignment? Princeton [in English].

15. Niedermayer O. (1996). Zur systematischen analyse der entwicklung von parteiensystemen. Wahlen und politische einstellungen in westlichen demokratien. O. W. Gabriel, J. W. Falter (Hrsg.). (s. 19-49). Frankfurt am Main: Lang [in German].

16. Ware A. (1996). Political parties and party systems. Oxford, New York [in English].

17. Helms L. (1999). Parteien und fraktionen. Ein internationaler vergleich. Opladen [in German].

18. Honiukova L. (2009). Politychni partii yak instytut derzhavnoi polityky ta upravlinnia: teoretyko-metodolohichnyi analiz [Political parties as an institute of state policy and management: theoretical and methodological analysis]. Kyiv [in Ukrainian].

19. Kotsiuruba O. (2013). Publichne finansuvannia politychnykh partii: perspektyva dlia Ukrainy na dosvidi Polshchi [Public funding of political parties: a prospect for Ukraine on the experience of Poland]. Visnyk Lvivskoho universytetu. Seriia yurydychna Visnyk of Lviv University. Series: Law, 57, 179-188 [in Ukrainian].

20. Obushnyi S. M. (2007). Finansove zabezpechennia diialnosti politychnykh partii v Ukraini [Financial support of political parties in Ukraine]. Candidate's thesis. Kyiv [in Ukrainian].

21. Prymush M. V. (2001). Polityko-pravove rehuliuvannia diialnosti politychnykh partii [Political and legal regulation of political parties activities]. Donetsk [in Ukrainian].
22. Martyniuk R. (2010). Partiina systema Ukrainy ta rehionalni chynnyky $\mathrm{v}$ yii rozvytku [The party system of Ukraine and regional factors in its development]. Politolohichni ta sotsiolohichni studii - Political science and sociology studies, 50 (9), 180-192 [in Ukrainian].

23. Romaniuk A. S., Shveda Yu. R., Shumelda O. V. (2003). Polityko-pravovi aspekty finansuvannia politychnykh partii: svitovyi dosvid ta Ukraina [Political and legal aspects of financing political parties: world experience and Ukraine]. Lviv [in Ukrainian].

24. Dzhuhan V. V. (2017). Konstytutsiinopravovi zasady finansuvannia politychnykh partii v Ukraini ta krainakh YeS: porivnialnyi analiz [Constitutional legal framework for financing political parties in Ukraine and EU countries: comparative analysis]. Candidate's thesis. Uzhhorod: Uzhhorodskyi natsionalnyi universytet [in Ukrainian].

25. Yanh L. (2002). Rehuliatsiia politychnoho finansuvannia $\mathrm{u}$ liberalno-demokratychnykh suspilstvakh [Regulation of Political Financing in Liberal-Democratic Societies]. Kyiv [in Ukrainian].

26. Williams R. (2000). Aspects of Party Finance and Political Corruption. Party Finance and Political Corruption. (p. 1-13). London: Macmillan [in English].

27. Yanisherskyi S. O. (n.d.). Derzhavne finansuvannia statutnoi diialnosti politychnykh partii: dosvid YeS i napriamy udoskonalennia vitchyznianoho zakonodavstva [State financing of statutory activities of political parties: EU experience and directions of improvement of domestic legislation]. www.niss.gov.ua. Retrieved from http://www.niss.gov.ua/articles/2900 [in Ukrainian].

28. Guidelines and Report on the Financing of Political Parties adopted 
by the Venice Commission at its $46^{\text {th }}$ Plenary Meeting (Venice, 9-10 March 2001). CDL-INF(2001)008-e. (n.d.). www.venice.coe.int. Retrieved from https://www.venice.coe.int/ webforms /documents $/$ ? pdf=CDLINF(2001)008-e [in English].

29. Rekomendatsiia N Rec (2003) 4 Komitetu ministriv Rady Yevropy derzhavam-chlenam "Pro zahalni pravyla borotby z koruptsiieiu pry finansuvanni politychnykh partii i vyborchykh kampanii" [Recommendation N Rec (2003) of the 4 Committee of Ministers of the Council of Europe to member states on "General rules for combating corruption in the financing of political parties and electoral campaigns”]. (n.d.). zakon.rada.gov.ua. Retrieved from https://zakon.rada.gov. ua/laws/show/994_867 [in Ukrainian].

30. Rekomendatsiia PARIe "Finansuvannia politychnykh partii" vid 22.05.2001, № 1516 (2001) [PACE Recommendation "Financing of $\mathrm{Po}^{-}$ litical Parties" dated May 22 2001, № 1516 (2001)]. (n.d.). crimecor.rada. gov.ua. Retrieved from http://crimecor.rada.gov.ua/komzloch/control/ uk/publish/article;jsessionid=DCB1 8A3AA744DB458FFEC474D147FA 17 ?art_id $=48962 \&$ cat_id $=46352$ [in Ukrainian].

31. Rekomendatsiia N Rec (2003) 4 Komitetu ministriv Rady Yevropy derzhavam-chlenam "Pro zahalni pravyla borotby z koruptsiieiu pry finansuvanni politychnykh partii i vyborchykh kampanii" [Recommendation N Rec (2003) of the 4 Committee of Ministers of the Council of Europe to member states on "General rules for combating corruption in the financing of political parties and electoral campaigns"]. (n.d.). zakon.rada.gov.ua. Retrieved from https://zakon.rada.gov.ua/laws/ show/994_867 [in Ukrainian].
32. Dzhuhan V. V. (2017). Konstytutsiinopravovi zasady finansuvannia politychnykh partii v Ukraini ta krainakh YeS: porivnialnyi analiz [Constitutional legal framework for financing political parties in Ukraine and EU countries: comparative analysis]. Candidate's thesis. Uzhhorod: Uzhhorodskyi natsionalnyi universytet [in Ukrainian].

33. Strom K. A. (1990). Behavioral theory of competitive political parties. American journal of political science, 34 (2), 565-598 [in English].

34. Schlesinger J. A. (1984). On the Theory of Party Organization. The Journal of Politics, 46 (2), 369-400 [in English].

35. Naßmacher, K.-H. (2009). The Funding of Party Competition: Political finance in 25 democracies. BadenBaden: Nomos [in English].

36. Recommendation 1516 (2001) "Financing of political parties" : adopted by Parliamentary Assembly of the Council of Europe on 22 May 2001. (n.d.). www.assembly.coe.int. Retrieved from http://www.assembly.coe. int/nw/xml/XRef/Xref-XML2HTML-en.asp?fileid=16907\&lang=en [in English].

37. van Biezen, I. (n.d.). Campaign and party finance. www.hks.harvard.edu. Retrieved from https://www.hks.harvard.edu/fs/pnorris/Acrobat/Chapter\%205\%20Van\%20Biezen\%20Campaign $\% 20$ and $\% 20$ party\%20finance. pdf [in English].

38. Monitorynh'2018: osnovni tendentsii zmin hromadskoi dumky [Monitoring'2018: the main tendencies of changes in public opinion]. (2018). dif. org.ua. Retrieved from https://dif.org. ua/article/monitoring2018-osnovnitendentsii-zmin-gromadskoi-dumki [in Ukrainian].

39. Tsatsos D., Bleckmann A., Bothe M. (1965). Die Finanzierung politischer Parteien: ein rechtsvergleichender 
Uberblick. Zeitschrift für ausländisches öffentliches Recht und Völkerrecht, 25, 524-550 [in German].

40. Kopecký P. (2006). Political parties and the state in post-communist Europe: The nature of symbiosis. Journal of Communist Studies and Transition Politics, 22, 251-273 [in English].

41. Zakon Ukrainy "Konstytutsiia Ukrainy" : vid 28.06.1996 r. [The Law of Ukraine "The Constitution of Ukraine" from 28.06.1996].(n.d.).zakon.rada. gov.ua. Retrieved from http:// zakon 2 .rada.gov.ua/laws / $\mathrm{show} / 254 \%$ D $0 \%$ B A / 96 $\% \mathrm{D} 0 \% \mathrm{~B} 2 \% \mathrm{D} 1 \% 80$ [in Ukrainian].
42. Zakon Ukrainy "Pro politychni partii v Ukraini” : vid 01.10.2018, № 2365III [Law of Ukraine "On Political Parties in Ukraine” from 01.10.2018, № 2365-III]. (n.d.), zakon.rada.gov. ua. Retrieved from https://zakon. rada.gov.ua/laws/show/2365-14 [in Ukrainian].

43. Zakon Ukrainy "Pro vybory narodnykh deputativ Ukrainy" : vid 25.03.2004 r.[Law of Ukraine "On the election of people's deputies of Ukraine" from 25.03.2004]. (n.d.). zakon.rada.gov.ua. Retrieved from http://zakon5.rada.gov.ua/laws/ show/1665-15/ed20060318/page [in Ukrainian]. 